\title{
Identification of Resistance to New Virulent Races of Rust in Sunflowers and Validation of DNA Markers in the Gene Pool
}

\author{
Lili Qi, Tom Gulya, Gerald J. Seiler, Brent S. Hulke, and Brady A. Vick
}

U.S. Department of Agriculture-Agricultural Research Service, Northern Crop Science Laboratory, 1605 Albrecht Blvd., Fargo, ND $58102-2765$. Accepted for publication 20 September 2010.

\begin{abstract}
Qi, L.-L., Gulya, T., Seiler, G. J., Hulke, B. S., and Vick, B. A. 2011. Identification of resistance to new virulent races of rust in sunflowers and validation of DNA markers in the gene pool. Phytopathology 101:241249.

Sunflower rust, caused by Puccinia helianthi, is a prevalent disease in many countries throughout the world. The U.S. Department of Agriculture (USDA)-Agricultural Research Service, Sunflower Research Unit has released rust resistant breeding materials for several decades. However, constantly coevolving rust populations have formed new virulent races to which current hybrids have little resistance. The objectives of this study were to identify resistance to race 336 , the predominant race in North America, and to race 777, the most virulent race currently known, and to validate molecular markers known to be linked to rust resistance genes in the sunflower gene pool. A total of 104 entries, including 66
\end{abstract}

ABSTRACT released USDA inbred lines, 14 USDA interspecific germplasm lines, and 24 foreign germplasms, all developed specifically for rust resistance, were tested for their reaction to races 336 and 777 . Only 13 of the 104 entries tested were resistant to both races, whereas another six were resistant only to race 336 . The interspecific germplasm line, Rf ANN1742, was resistant to both races and was identified as a new rust resistance source. A selection of 24 lines including 19 lines resistant to races 777 and/or 336 was screened with DNA markers linked to rust resistance genes $R_{1}, R_{2}, R_{4 u}$, and $R_{5}$. The results indicated that the existing resistant lines are diverse in rust resistance genes. Durable genetic resistance through gene pyramiding will be effective for the control of rust.

Additional keywords: DNA markers, sequence characterized amplified region, simple sequence repeat.
Sunflower rust, caused by Puccinia helianthi Schwein., has been an increasing threat to the sunflower industry in North America in the last few years since sunflower rust has been appearing earlier in the season than normal, which increases the likelihood of significant economic losses to the disease $(24,26)$. Rust incidence has continued to increase from $17 \%$ in 2002 to over $70 \%$ of the fields in the last 2 years $(1,12,26)$. In addition, there has been an exponential increase in the appearance of virulent rust races to which current hybrids have little resistance $(10,39)$. Although fungicides are available for disease management, host plant resistance is the most effective way to control the disease.

In the early 1960s, four North American (NA) races (1, 2, 3, and 4) of $P$. helianthi were identified by Sackston (43) using three standard Canadian sunflower rust differential lines, allowing a maximum of $2^{3}$ races to be differentiated. Later, this sequential numbering system of race identification was changed to a coded triplet system to produce a virulence formula using a set of nine differentials, which allows a theoretical $2^{9}$ races to be identified, assuming no duplication of genes between lines $(12,25)$. An international ad hoc committee approved the use of these lines and the triplet code for rust nomenclature (13). In some instances, researchers have added supplemental differentials to the list, using selections from rust resistant hybrids commonly grown in their country (20). To compare the older race classification system and the triplet coding system, the previous NA race 1 corresponds to race 100 of the coded triplet system, NA race 2 to race 500, NA

Corresponding author: L. L. Qi; E-mail address: lili.qi@ars.usda.gov

doi:10.1094/PHYTO-06-10-0162

This article is in the public domain and not copyrightable. It may be freely reprinted with customary crediting of the source. The American Phytopathological Society, 2011. race 3 to race 300 , and NA race 4 to race 700 . The differentials used in this system include inbred line S37-388, Canadian lines MC 90 and MC 29, P-386, and inbred lines HA-R1 through HAR5. S37-388 is universally susceptible to all races, and others have different reaction patterns, and are all derived from diverse pedigrees (14). Evaluation of a collection of rust races from both cultivated and wild sunflower that was conducted in 2007 and 2008 in the United States identified a total of 39 rust races (12). Among them, two races 334 and 336, variants of race 300 (old race 3), were dominant in both years comprising 49\% in 2007 and $39 \%$ in 2008 . Race 336 is able to attack six of the nine differential lines. Although race 777, a variant of race 700 (old race 4), was present at low frequency, it is the most virulent race. The nine differential lines are all susceptible to race $777(12,40)$, and only a few lines are resistant to this highly virulent race of rust $(16,34)$.

Host resistance genes have been genetically characterized in sunflower. The rust resistance gene $R_{l}$ present in the inbred lines MC 69 and MC 90 confers resistance to rust races 100 and 500 (old races 1 and 2) (27,37). A sequence characterized amplified region (SCAR) marker SCT06 ${ }_{950}$ was found that cosegregates with rust resistance gene $R_{I}$ and mapped to linkage group (LG) 8 $(23,51)$. The inbred line MC 29 has the rust gene $R_{2}$, resistant to races 100 and 300 (old races 1 and 3) (27,37). Rust gene $R_{3}$ identified in the line PhRR3 confers resistance to two Australian rust races (8), while gene $R_{4}$ in the inbred lines HA-R1, HA-R3, HA-R4, and HA-R5, confers resistance to races 100, 500, 300, and 700 (old races 1 to 4 ) $(9,35)$. The $R_{4}$ locus is located on LG 13 in Helianthus annuus L. (45). A SCAR marker SCX20 600 linked to rust gene $R_{a d v}$ present in the proprietary line P2 developed by Pioneer Seeds (Pioneer Hi-Bred Australia) was also mapped to LG $13(23,51)$. The rust gene $R_{5}$ in the inbred line HA$\mathrm{R} 2$ confers resistance to races 100, 500, 300, and 700 (old races 1 to 4) $(9,35)$. Several SSR markers in LG 13 were reported to be linked to rust gene $R_{5}(45)$. Yang et al. (50) identified the rust gene 
$\mathrm{Pu}_{6}$ in the inbred line P-386 that confers resistance to races 100 , 500,300 , and 700 (old races 1 to 4 ). Rust resistance to races 100, 500,300 , and 700 (old races 1 to 4 ) was also reported in wild annual sunflower species $(11,38)$.

The USDA Sunflower Research Unit has released more than 300 sunflower breeding lines since 1968. Of those, 74 lines were reported to have resistance to one or more NA races of rust (http://www.ars-grin.gov/cgi-bin/npgs/html/desc.pl?79148; http:// www.ars-grin.gov/cgi-bin/npgs/html/dno_eval_acc.pl?79149, last accessed 11 June 2010, Table 1). However, resistance to the predominant race 336 and the most virulent race 777 has not been evaluated in these lines because these races did not exist at the time the breeding lines were released. Also, the genetic diversity of the wild Helianthus species has not been fully evaluated for resistance to the new races. The objectives of the present study were to identify resistance to the races 336 and 777 in sunflower breeding lines and to validate molecular markers known to be linked to resistance genes in the sunflower rust resistance gene pool.

\section{MATERIALS AND METHODS}

Plant materials. A total of 80 USDA released sunflower lines were selected for this study based on previous reports of rust resistance from greenhouse evaluations using races 300 and 700 (old races 3 and 4) from 1993 through 1997 (http://www.ars-

TABLE 1. List of selected materials that previously reported resistance to different rust pathotypes used in the present study

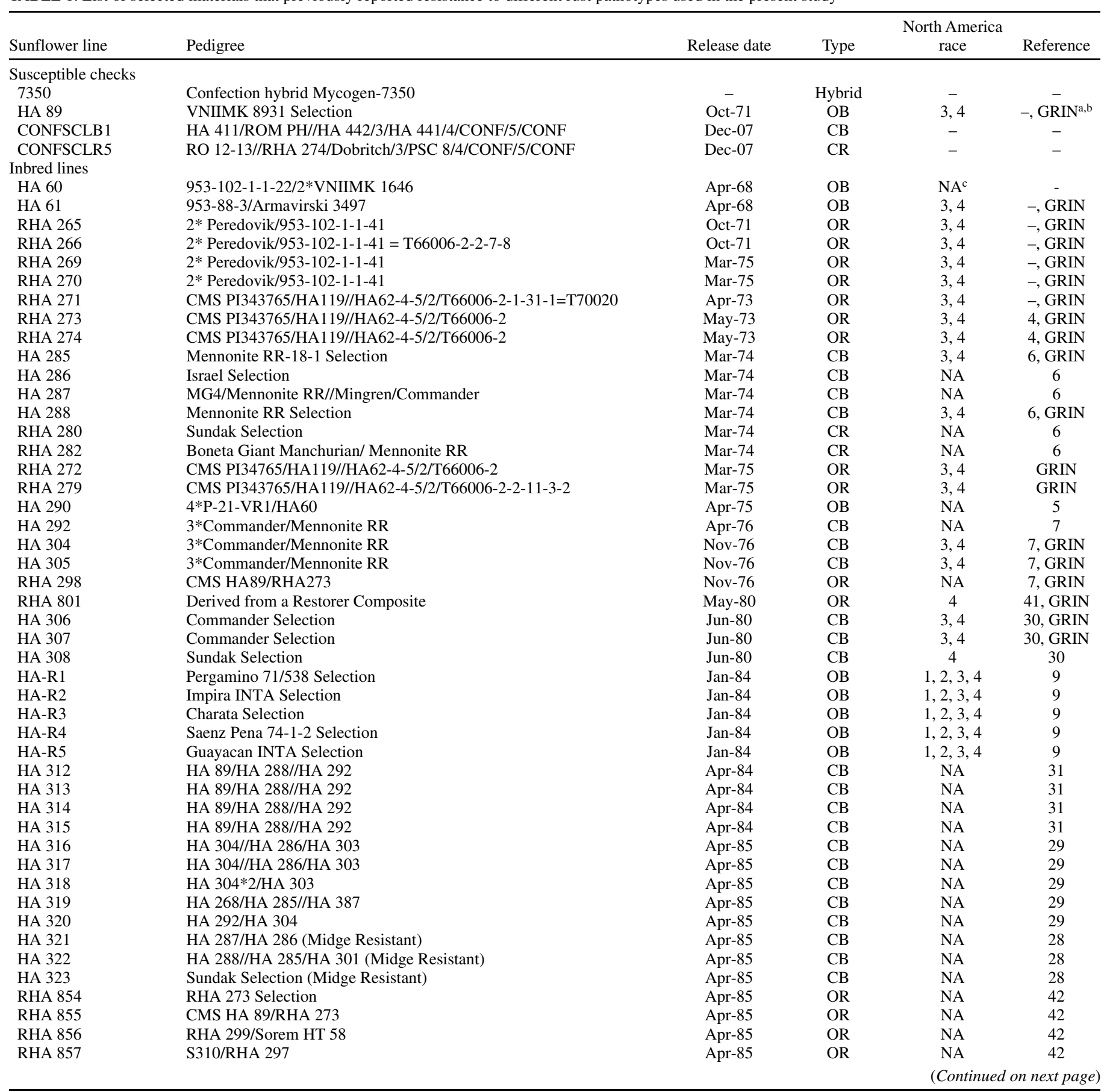

${ }^{a}$ GRIN for race 3 test: http://www.ars-grin.gov/cgi-bin/npgs/html/desc.pl?79148.

${ }^{\mathrm{b}}$ GRIN for race 4 test: http://www.ars-grin.gov/cgi-bin/npgs/html/desc.pl?79149.

${ }^{c} \mathrm{NA}$, rust race information is not available. 
grin.gov/cgi-bin/npgs/html/desc.pl?79148; last accessed 11 June 2010) and published registrations for germplasm releases (Table $1)$. The selected lines included nine oil-B lines (OB), 26 oil-R lines (OR), 28 confection-B lines (CB), three confection- $\mathrm{R}$ lines (CR), and 14 interspecific germplasm lines (Table 1). Of the 14 interspecific lines, eight, PH1 through PH7 and TX16R selected from the cross of the inbred line HA 89 with wild $H$. annuus L., $H$. argophyllus T. \& G., and $H$. petiolaris sp. petiolaris Nutt. populations were resistant to the four races 100, 300, 500, and 700 (old races 1 to 4 ) at the time of their releases (Table 1) $(18,19)$. Another six were selected from the $\mathrm{BC}_{1} \mathrm{~F}_{2}$ populations of HA 89 crossed with different wild $H$. annuus populations; their resistance to sunflower rust had not been previously evaluated (44). Additionally, 24 foreign germplasms, developed specifically for rust resistance from Argentina, Australia, Canada, France, and Russia, were included in the present study; some of them possessed known rust resistance genes. The confection hybrid Mycogen 7350 was used as a universal susceptible check, replacing the Canadian public line S37-388 which is difficult to increase because of its extreme rust susceptibility. The inbred lines HA 89, CONFSCLB1, and CONFSCLR5 were also used as susceptible checks.

To study the inheritance of a new rust resistance gene identified in the line $\mathrm{Rf}$ ANN-1742 in the present study, an $\mathrm{F}_{2}$ segregating

TABLE 1.(Continued from previous page)

\begin{tabular}{|c|c|c|c|c|c|}
\hline Sunflower line & Pedigree & Release date & Type & $\begin{array}{c}\text { orth Ameri } \\
\text { race }\end{array}$ & Reference \\
\hline RHA 858 & P1161/RHA 298 & Apr-85 & OR & NA & 42 \\
\hline RHA 859 & NSH 43/RHA 299 & Apr-85 & OR & NA & 42 \\
\hline HA 349 & HA $292 * 2 /$ Pervenets High Oleic & Apr-86 & $\mathrm{CB}$ & NA & 36 \\
\hline HA 350 & HA $292 * 2 /$ Pervenets High Oleic & Apr-86 & $\mathrm{CB}$ & NA & 36 \\
\hline HA 351 & HA $292 * 2 /$ Pervenets High Oleic & Apr-86 & $\mathrm{CB}$ & NA & 36 \\
\hline HA 352 & HA $292 * 2 /$ Pervenets High Oleic & Apr-86 & $\mathrm{CB}$ & NA & 36 \\
\hline HA 353 & HA $292 * 2 /$ Pervenets High Oleic & Apr-86 & $\mathrm{CB}$ & NA & 36 \\
\hline RHA 344 & RHA $274 * 2 /$ Pervenets High Oleic & Apr-86 & OR & NA & 36 \\
\hline RHA 345 & RHA $274 * 2 /$ Pervenets High Oleic & Apr-86 & OR & NA & 36 \\
\hline RHA 346 & RHA $274 * 2 /$ Pervenets High Oleic & Apr-86 & OR & NA & 36 \\
\hline RHA 347 & RHA $274 * 2 /$ Pervenets High Oleic & Apr-86 & OR & NA & 36 \\
\hline RHA 348 & RHA $274 * 2 /$ Pervenets High Oleic & Apr-86 & OR & NA & 36 \\
\hline RHA 340 & HA $89 * 3 / H$. argophyllus 415 & Apr-86 & OR & 4 & 32 \\
\hline RHA 397 & RHA 274/RO-20-10-3-3-2 (South African line) & May-93 & OR & 6 & 33 \\
\hline HA-R6 & HA 323/Ames 3234 (PI 650362 = France 6 SC U6 L6) & May-97 & $\mathrm{CB}$ & 777 & 34 \\
\hline HA-R7 & RHA 324/Ames 3234 (PI 650362 = France 6 SC U6 L6) & May-97 & CR & 777 & 34 \\
\hline HA-R8 & RHA 377/PI 432512 (Havasupai landrace-Arizona) & May-97 & OR & 777 & 34 \\
\hline HA460 & HA434*3/RHA340 & May-06 & OB & NA & 17 \\
\hline RHA 464 & RHA 418/RHA 419/3/ RHA 801//RHA 365/PI 413047 & May-06 & OR & NA & 16 \\
\hline \multicolumn{6}{|l|}{ Germplasms } \\
\hline Rf ANN-19 & cmsHA89*2/South Dakota H. annuus (Acc. 19) & Nov-97 & - & - & 43 \\
\hline Rf ANN-48 & cmsHA89*2/South Dakota H. annuus (Ames 6149) & Nov-97 & - & - & 43 \\
\hline Rf ANN-783 & cmsHA89*2/California $H$. annuus (PI 435593) & Nov-97 & - & - & 43 \\
\hline Rf ANN-892 & cmsHA89*2/Arizona H. annuus (PI 435620) & Nov-97 & - & - & 43 \\
\hline Rf ANN-1064 & cmsHA89*2/North Dakota H. annuus (PI 468439) & Nov-97 & - & - & 43 \\
\hline Rf ANN-1742 & cmsHA89*2/Oklahoma $H$. annuus (PI 613748) & Nov-97 & - & - & 43 \\
\hline PH1 & HA 89//PI 413023 (Colorado wild H. annuиs)/HA 89*2 & Sep-04 & - & $1,2,3,4$ & 19 \\
\hline $\mathrm{PH} 2$ & HA 89//PI 413037 (Nebraska wild H. annuus)/HA 89*2 & Sep-04 & - & $1,2,3,4$ & 19 \\
\hline PH3 & HA 89//PI 413038 (South Dakota wild H. annuus)/HA 89*2 & Sep-04 & - & $1,2,3,4$ & 19 \\
\hline PH4 & HA 89//PI 413048 (California wild H. annuus)/HA 89*2 & Sep-04 & - & $1,2,3,4$ & 19 \\
\hline PH5 & HA 89//PI 413118 (California wild $H$. annuus)/HA 89*2 & Sep-04 & - & $1,2,3,4$ & 19 \\
\hline PH6 & HA 89//PI 413171 (Texas H. argophyllus)/HA 89*2 & Sep-04 & - & $1,2,3,4$ & 19 \\
\hline PH7 & HA 89//PI 413175 (Nebraska H. petiolaris)/HA 89*2 & Sep-04 & - & $1,2,3,4$ & 19 \\
\hline TX16R & TX16 (Texas wild $H$. annuus)/HA89//TX16/HA89 & Jul-06 & - & $1,2,3,4$ & 18 \\
\hline \multicolumn{6}{|l|}{ Introduced lines } \\
\hline MC 29 & Canadian line susceptible X 953-88 (Texas wild $H$. annuus) & - & - & 1,3 & 37 \\
\hline MC 69 & Canadian line susceptible X 953-102 (Texas wild H. annuus) & - & - & 1,2 & 37 \\
\hline MC 90 & - & - & - & 1,2 & 27 \\
\hline P-386 & Selection from Charata INTA & - & - & $1,2,3,4$ & 22,49 \\
\hline PhRR3 & Backcross between S37-388 and Hysun 33s & - & - & NA & 8 \\
\hline Suncross 40R & Commercial hybrid of Agseeds Research & - & - & NA & 45 \\
\hline Suncross 53 & Commercial hybrid of Agseeds Research & - & - & NA & 45 \\
\hline Hysun 36 & Commercial hybrid of Pacific Seeds Pty Ltd. & - & - & NA & 45 \\
\hline Hysun 37 & Commercial hybrid of Pacific Seeds Pty Ltd. & - & - & NA & 45 \\
\hline Hysun 45 & Commercial hybrid of Pacific Seeds Pty Ltd. & - & - & NA & 45 \\
\hline Hysun 47 & Commercial hybrid of Pacific Seeds Pty Ltd. & - & - & NA & 45 \\
\hline A999-38-6-4 & A selection of A89//Advantage & - & - & NA & 45 \\
\hline B55RR & A selection of Advance Self & - & - & NA & 45 \\
\hline SP74 & Australian selection from $\mathrm{Ar}$ & - & - & NA & 45 \\
\hline MP555 A1 & “Mezcla precoz"-INTA Pergamino sel. Castelar & - & - & NA & 3 \\
\hline MP 557A & "Mezcla precoz"-INTA Pergamino sel. Castelar & - & - & NA & 3 \\
\hline LC 74/75-20620 & “Mezcla precoz”-INTA Pergamino & - & - & NA & 3 \\
\hline P 94A & Line from Continental Co. (Arg) derived by cross with wild $H$. annuus & - & - & NA & - \\
\hline PB 67B & Selection of cultivar Pehuen INTA & - & - & NA & - \\
\hline PI 380571 & University of Minnesota-Crookston (breeding line) & - & - & NA & - \\
\hline PI 650362 & France line 6 SC U6 L6 & - & - & NA & - \\
\hline PI 497938 & Russian Federation (cultivar)-TA 3697 (VIR 2704) & - & - & NA & - \\
\hline PI 507890 & Hungary (Landrace)-3100392 & - & - & NA & - \\
\hline PI 650539 & Pergamino $71 / 538$ & - & - & NA & - \\
\hline
\end{tabular}


population was developed from the selected resistant plants heterozygous for the rust resistance gene.

Rust inoculation. Seeds were planted in 36-cell plastic flats (each cell $4.6 \mathrm{~cm} \times 5.4 \mathrm{~cm}$ ) filled with Sunshine SB 100B potting mixture (SunGro Horticulture, Bellevue, WA). For inbred lines, two replicates of four plants (one plant/cell), in separate flats, were planted, while for germplasm lines a total of 20 plants were tested because the germplasms were not genetically fixed and it was unknown if the rust resistance genes were homozygous. The inheritance of rust resistance in the line Rf ANN-1742 was evaluated using an $\mathrm{F}_{2}$ segregating population, with a total of $208 \mathrm{~F}_{2}$ plants inoculated for each of the two rust races. The greenhouse was maintained at $24^{\circ} \mathrm{C}$ day $/ 20^{\circ} \mathrm{C}$ night with a 16 -h photoperiod and sodium vapor lighting. Plants were fertilized weekly with a water soluble 15-16-17 analysis fertilizer and sprayed weekly to runoff with B-Nine (daminozide; Chemtura USA, Middlebury, CT) growth regulator at $0.5 \% \mathrm{wt} / \mathrm{vol}$ to maintain compact growth. The inbred lines and germplasm lines were inoculated with urediniospores of race 336 and race 777 (separately on two groups of plants) at the four-leaf stage (about 3 weeks after planting) using the procedure described by Gulya and Masirevic (14). Race 336 was collected originally from cultivated plants in North Dakota in 2009, and is the predominant race in North Dakota, while race 777 , collected from cultivated sunflower plants in Kansas in 1995, is the most virulent race, able to infect all nine rust differential lines. Both races were increased from single pustules. Urediniospores were collected from greenhouse-grown Mycogen hybrid 7350 plants with the aid of a cyclone collector (48) and stored at $4^{\circ} \mathrm{C}$ or $-80^{\circ} \mathrm{C}$ until needed. Spores were suspended in SOLTROL 170 isoparaffin (Chevron Phillips Chemical Co., The Woodlands, TX) at 5 to $10 \mathrm{mg}$ spores $/ 10 \mathrm{ml}$, which was equivalent to 1.5 to $3.0 \times 10^{6}$ spores $/ \mathrm{ml}$. The spore suspension was atomized onto all leaf surfaces with compressed air. After allowing the SOLTROL 170 to evaporate for $15 \mathrm{~min}$, the plants were incubated in sealed chambers equipped with automated ultrasonic humidifiers to provide continuous leaf wetness within a room maintained at 18 to $20^{\circ} \mathrm{C}$ in the dark for 16 to $24 \mathrm{~h}$. Plants were then returned to the greenhouse and maintained under the conditions mentioned above.

Rust evaluation. Rust pustules started to appear in 7 to 10 days, but evaluations were made at 12 to 14 days postinoculation. Rust reaction was rated visually on the basis of both pustule size (infection type) and leaf area covered by pustules (severity) on all inoculated leaves (first four leaves of each plant). A total of 32 leaves for each inbred line and 80 leaves for each germplasm line were evaluated. A modified Sackston's numerical rating system (43) described by Yang et al. (49) was used as follows: $0=$ immune, no uredia or hypersensitive flecks; 1 = high resistance, presence of hypersensitive flecks or lesions, or pustules smaller than $0.2 \mathrm{~mm}$ in diameter with or without chlorotic halo; $2=$ resistant, pustules smaller than $0.4 \mathrm{~mm} ; 3=$ susceptible, pustules 0.4 to $0.6 \mathrm{~mm}$ in diameter; and $4=$ highly susceptible, pustules larger than $0.6 \mathrm{~mm}$. Reactions 0,1 , and 2 were classified as resistant, while reactions 3 and 4 were rated as susceptible. Pustule leaf coverage was assessed using the diagrams developed by Gulya et al. (15). Pustule leaf coverage of $<0.5 \%$ combined with pustule size ratings of 2 were classified as resistant. Susceptible check varieties, Mycogen hybrid 7350, and USDA lines HA 89,
CONFSCLB1, and CONFSCLR5, had rust ratings of 3 or 4 and pustule coverages of 10 to $20+\%$. For the segregated $F_{2}$ population of the line $\mathrm{Rf} \mathrm{ANN}-1742$, the observed ratios of resistant to susceptible plants were compared with expected ratios using chisquare to test for goodness of fit.

DNA marker analysis. Sunflower lines resistant to rust race 336 or 777 , and the lines with known rust resistance genes, were selected for further genotyping using six known DNA markers linked to rust resistance genes (Table 2). Simple sequence repeat (SSR) markers were developed by Tang et al. $(46,47)$ and Yu et al. (51). Total DNA was extracted from four seedlings per line using the Qiagen DNeasy plant mini kit. Polymerase chain reaction (PCR) with SSR primers was performed in a 15 - $\mu$ l volume containing $2 \mathrm{mM} \mathrm{MgCl}_{2}, 200 \mu \mathrm{M}$ of each dNTP, $0.02 \mu \mathrm{M}$ forward primer with an M13 tail (CACGACGTTGTAAAACGAC) at the 5' end, $0.1 \mu \mathrm{M}$ reverse primer, $0.1 \mu \mathrm{M}$ fluorescently labeled M13 primer, $1 \times$ PCR buffer, 0.5 units Taq polymerase (Bioline, Randolph, MA), and 10 to $20 \mathrm{ng}$ of genomic DNA. The PCR reactions were performed in a Peltier thermocycler (Bio-Rad Lab, Hercules, CA) with a touchdown program. The PCR conditions were as follows: $95^{\circ} \mathrm{C}$ for $3 \mathrm{~min}$; followed by 10 cycles in which the annealing temperature was decreased by $0.5^{\circ} \mathrm{C}$ for each cycle starting at $94^{\circ} \mathrm{C}$ for $45 \mathrm{~s}$, and then $64^{\circ} \mathrm{C}$ for $45 \mathrm{~s}$, and $72^{\circ} \mathrm{C}$ for $1 \mathrm{~min}$, followed by an additional 35 cycles of $94^{\circ} \mathrm{C}$ for $45 \mathrm{~s}, 58^{\circ} \mathrm{C}$ for $45 \mathrm{~s}$, and $72^{\circ} \mathrm{C}$ for $1 \mathrm{~min}$. Extension of the amplified fragments was achieved at $72^{\circ} \mathrm{C}$ for $20 \mathrm{~min}$. Electrophoresis was carried out using an IR2 4300 DNA Analyzer (Li-COR) on 6\% polyacrylamide gel. The PCR conditions for SCAR marker SCT06 linked to the rust gene $R_{l}$ were previously described in Lawson et al. (23). The PCR products were separated in $1.5 \%$ agarose gels and visualized under UV light.

\section{RESULTS}

Evaluation of rust resistance to virulent races. The reactions of 104 sunflower lines to races 336 and 777 indicated that most previously released lines, originally selected for resistance to the four old NA rust races, were susceptible to races 336 and 777 . Only $13(12.5 \%)$ of the 104 entries tested were resistant to both races, and another six lines were resistant just to race 336 (Table 3 ). Among the 19 resistant lines, six were released USDA inbred lines, six were interspecific germplasm lines, and seven were introduced foreign lines. Most of the 19 rust resistant lines had a hypersensitive reaction with flecks or type 1 pustules. Germplasm line TX16R was the only entry with an immune reaction on some plants, but this entry was segregating

Six of the 66 inbred lines tested were resistant to one or both races. HA-R2 and HA-R3 were resistant to race 336, but moderately susceptible to race 777 . Four inbred lines, HA-R6, HA-R8, RHA 397, and RHA 464, were resistant to both races 336 and 777. Eight interspecific germplasm lines, PH1 to PH7 and TX16R, were previously reported to resist races 100, 500, 300, and 700 (old races 1 to 4) $(18,19)$. In our present study, PH3, PH4, and PH5 showed resistance to both races 336 and 777 with type 1 hypersensitive flecks or pustules, whereas PH6 was resistant only to race 336 (Table 3). The interspecific line TX16R had plants with two types of resistant reactions after inoculation: immune, and type 1 with a few hypersensitive flecks. The lines PH4

TABLE 2. Selected DNA markers linked to the rust resistance genes for marker validation used in the present study

\begin{tabular}{|c|c|c|c|c|c|c|}
\hline Resistance source & Resistance locus & Markers & Polymorphism & Linkage (cM) & Linkage group & Reference \\
\hline RHA 279 & $R_{l}$ & SCT06 950 & Dominant-coupling & 0 & 8 & 23 \\
\hline MC 29 & $R_{2}$ & ORS333 & Dominant-repulsion & 0 & 9 & W. R. Lawson, personal communication \\
\hline \multirow[t]{2}{*}{ Suncross 53} & \multirow[t]{2}{*}{$R_{4 u}$} & ORS799 & Codominant & 3.4 & 13 & 45 \\
\hline & & ORS45 & Codominant & 0 & 13 & 45 \\
\hline \multirow[t]{2}{*}{ HA-R2 } & \multirow[t]{2}{*}{$R_{5}$} & ORS316 & Codominant & 4.1 & 13 & 45 \\
\hline & & ORS630 & Dominant-repulsion & 0 & 13 & 45 \\
\hline
\end{tabular}


to PH6 and TX16R were segregating for resistance and susceptibility, indicating that rust resistance genes in these lines are still in a segregating condition.

Six other interspecific germplasm lines, which were derived from the crosses of different wild $H$. annuus populations with cultivated sunflower and released as fertility restorers (Rf) in 1997 (44), were tested for their reactions to rust (Table 1). One line, Rf ANN-1742, was found to be resistant to both rust races 336 and 777, whereas all others were highly susceptible to rust (Table 3). Segregation for rust resistance in the line Rf ANN-1742 indicated that the original single plant selection was heterozygous for the rust resistance gene. Among 26 foreign entries tested, Australian hybrids, Hysun 36, Hysun 37, Hysun 47, and PI 650362 (breeding line from INRA-France) were resistant to both races. Another three lines, MC 29 (Canada), Suncross 53 (Australian hybrid), and PI 497938 (Russia), were resistant only to race 336 (Table 3). PI 650362 is the resistance donor for the inbred line HA-R6 (Table 1).

Inheritance of a new rust resistance gene in line $\mathrm{Rf} A \mathrm{NN}$ 1742. The germplasm line $\mathrm{Rf} A N N-1742$ segregated for rust resistance to both races 336 and 777 in the first rust evaluation experiment and was identified as a new rust resistant source. The resistant plants (09-519-1 and 09-519-5) were selected and selfpollinated. Forty progenies from each selected plant were further evaluated for their reaction to both races. The results indicated that both selected plants were still heterozygous for the rust resistance gene, and their progenies equate to an $F_{2}$ segregating population. A total of $414 \mathrm{~F}_{2}$ progenies were further evaluated for their reaction to rust; 208 for race 336 and 206 for race 777 . The distribution of resistant to susceptible plants in the segregating population was a good fit to a 3:1 ratio. Of 208 plants tested with race 336, 153 plants were resistant, whereas 55 plants were susceptible $\left(\chi^{2}=0.06,0.90>P>0.75\right)$. Similar results were observed in the 206 progenies inoculated with race $777 ; 148$ plants were resistant, whereas 58 plants were susceptible $\left(\chi^{2}=0.27\right.$, $0.75>P>0.50)$. These results indicated that line Rf ANN-1742 has a single dominant gene conferring resistance to rust races 336 and 777.

DNA marker validation in the sunflower rust resistance gene pool. A selection of 24 lines was screened with SCAR and SSR markers linked to rust resistance genes. They included the 19 lines resistant to the races 777 and/or 336 identified in this study, four lines with known rust resistance genes $\left(R_{1}, R_{2}\right.$, and $\left.R_{3}\right)$, and one susceptible check HA 89 (Table 3 ). The SCAR primers SCT06a/SCT06b for the $\mathrm{R}_{1}$ locus amplified a 950-bp fragment in the lines MC 90 and RHA 279, which both harbor the $R_{l}$ gene This fragment was absent in the susceptible parent HA 89 (23). Among 24 tested lines, five lines, MC 29, HA-R8, RHA 397, RHA 464, and PI 497938, had the same PCR pattern as MC 90 and RHA 279, showing the presence a 950-bp fragment, and HAR8 also had an additional PCR fragment (Table 4, Fig. 1A).

SSR primers of ORS333 amplified three fragments which were previously mapped to LGs 3,9 , and 14 of sunflower $(2,47)$. A 150-bp fragment of ORS333 mapped to LG 9 was found to cosegregate with the rust resistance gene $R_{2}$ in the line MC 29 (W. R. Lawson, personal communication). We validated this marker with two mapping parents, HA 821 and MC 29, and 23 selected lines. As expected, the ORS333 primer amplified three fragments. Two fragments, 135 and $460 \mathrm{bp}$, are similar in the two parents, whereas a 150-bp fragment was present in the line HA 821, but absent in line MC 29, making OSR333 a dominant-repulsion marker for the $R_{2}$ gene (data not shown). Among the 23 lines tested with ORS333, three lines, MC 90, PhRR3, and PI 497938, had a similar PCR pattern to that of MC 29 with a missing 150-bp fragment (Table 4).

The molecular marker linked to the rust gene $R_{a d v}$ was developed using the proprietary line $\mathrm{P}_{2}$ as the resistant parent (23). This line is a commercial inbred line developed by Pioneer Hi-Bred

TABLE 3. Reactions to selected rust races of resistant lines

\begin{tabular}{|c|c|c|c|c|c|c|c|}
\hline \multirow[b]{3}{*}{ Sunflower line } & \multirow[b]{3}{*}{ Type } & \multicolumn{4}{|c|}{ Reaction to race } & & \\
\hline & & \multicolumn{2}{|c|}{336} & \multicolumn{2}{|c|}{777} & \multicolumn{2}{|c|}{ Putative rust gene $(s)^{c}$} \\
\hline & & $\mathrm{IT}^{\mathrm{a}}$ & Severity $(\%)^{\mathrm{b}}$ & IT & Severity $(\%)$ & Gene (s) & Linkage group \\
\hline \multicolumn{8}{|c|}{ Susceptible checks } \\
\hline 7350 & Hybrid & 4 & $10-20$ & 4 & $10-20$ & & \\
\hline HA 89 & $\mathrm{OB}$ & 4 & $10-20$ & 4 & $10-20$ & & \\
\hline CONFSCLB1 & $\mathrm{CB}$ & 4 & $10-20$ & 4 & $10-20$ & & \\
\hline CONFSCLR5 & $\mathrm{CR}$ & 4 & $10-20$ & 4 & $10-20$ & & \\
\hline \multicolumn{8}{|l|}{ Inbred lines } \\
\hline HA-R2 & $\mathrm{OB}$ & 2 & 0.5 & 3 & $0.5-1$ & $R_{5}$ & 13 \\
\hline HA-R3 & $\mathrm{OB}$ & 1 & 0.1 & 3 & 0.5 & $R_{4 b}$ & 13 \\
\hline HA-R6 & $\mathrm{CB}$ & 1 & 0 & 1 & 0 & & \\
\hline HA-R8 & $\mathrm{CR}$ & 1 & 0 & 1 & 0 & & \\
\hline RHA 397 & OR & 1 & 0.1 & 1 & 0 & & \\
\hline RHA 464 & OR & 1 & 0.1 & 2 & 0.1 & & \\
\hline \multicolumn{8}{|l|}{ Germplasm lines } \\
\hline $\mathrm{PH} 3$ & - & 1 & 0 & 1 & 0 & $R_{4 m}$ & 13 \\
\hline $\mathrm{PH} 4^{\mathrm{d}}$ & - & 1 & 0 & 1 & 0.1 & & \\
\hline $\mathrm{PH}^{\mathrm{d}}$ & - & 1 & 0 & 1 & 0.5 & & \\
\hline PH6 $^{\mathrm{d}}$ & - & 1 & 0.1 & 4 & 5 & $R_{4 o}$ & 13 \\
\hline $\mathrm{TX} 16 \mathrm{R}^{\mathrm{d}}$ & - & 0.1 & 0 & 0.1 & 0 & & \\
\hline RF ANN-1742d & - & 1 & $0.1-0.5$ & 2 & $0.1-0.5$ & & \\
\hline \multicolumn{8}{|l|}{ Introduced lines } \\
\hline MC 29 & - & 1 & 0 & 3 & $0.5-1$ & $R_{2}$ & \\
\hline Suncross 53 & - & 1 & 0 & 3 & $0.5-1$ & $R_{4 u}$ & 13 \\
\hline Hysun 36 & - & 1 & 0 & 2 & 0.1 & & \\
\hline Hysun 37 & - & 1 & 0 & 1 & 0 & & \\
\hline Hysun 47 & - & 1 & 0 & 1 & 0 & & \\
\hline PI 497938 & - & 1 & 0 & 4 & 10 & & \\
\hline PI 650362 & - & 1 & 0.5 & 1 & 0 & & \\
\hline
\end{tabular}

a IT: infection type, 0 indicates immune, 1 to 2 indicates resistant, and 3 to 4 indicates susceptible (49).

b Severity: the percent leaf area affected by rust: $\leq 0.5 \%$, resistant; and $>0.5 \%$, susceptible (19).

c Sendall et al. (45).

d Resistance to rust was segregating. 
and is not publicly available. DNA markers linked to $R_{a d v}$ were not able to be validated in the present study. Of 24 lines tested with two markers, ORS45 and ORS799, linked to the rust gene $R_{4 u}$ in Suncross 53, only Hysun 47 had similar PCR patterns to Suncross 53 for these two markers (Table 4). PCR polymorphic fragments in these two lines could be distinguished from other lines only in a $6 \%$ denaturing polyacrylamide gel.

Of the 24 lines screened with markers ORS316 and ORS630 linked to the rust gene $R_{5}$ in line HA-R2, only MC 29 shared a common PCR pattern of ORS316 with HA-R2. However, six

TABLE 4. The results of sunflower lines screened with molecular markers linked to rust resistance genes

\begin{tabular}{|c|c|c|c|c|c|c|c|}
\hline \multirow[b]{2}{*}{ Line } & \multirow[b]{2}{*}{ Rust gene } & \multirow{2}{*}{$\frac{R_{l}}{\text { SCT06 }_{950}}$} & \multirow{2}{*}{$\begin{array}{c}R_{2} \\
\text { ORS333 }\end{array}$} & \multicolumn{2}{|c|}{$R_{4 u}$} & \multicolumn{2}{|c|}{$R_{5}$} \\
\hline & & & & ORS799 & ORS45 & ORS316 & ORS630 \\
\hline \multicolumn{8}{|l|}{ HA 89} \\
\hline MC 90 & $R_{l}$ & + & + & & & & \\
\hline RHA $279^{a}$ & $R_{1}$ & + & & & & & + \\
\hline MC $29^{a}$ & $R_{2}$ & + & + & & & + & \\
\hline PhRR3 & $R_{3}$ & & + & & & & \\
\hline HA-R3 & $R_{4 b}$ & & & & & & \\
\hline Suncross $53^{\mathrm{a}}$ & $R_{4 u}$ & & & + & + & & + \\
\hline $\mathrm{HA}-\mathrm{R} 2^{\mathrm{a}}$ & $R_{5}$ & & & & & + & + \\
\hline P-386 & $P_{u 6}\left(R_{4 e}\right)$ & & & & & & + \\
\hline \multicolumn{8}{|l|}{ HA-R6 } \\
\hline HA-R8 & & + & & & & & \\
\hline RHA 397 & & + & & & & & + \\
\hline RHA 464 & & + & & & & & \\
\hline Hysun 36 & & & & & & & + \\
\hline \multicolumn{8}{|l|}{ Hysun 37} \\
\hline Hysun 47 & & & & + & + & & \\
\hline PH3 & $R_{4 m}$ & & & & & & + \\
\hline \multicolumn{8}{|l|}{$\mathrm{PH} 4$} \\
\hline \multicolumn{8}{|l|}{ PH5 } \\
\hline PH6 & $R_{4 o}$ & & & & & & \\
\hline \multicolumn{8}{|l|}{ TX16R } \\
\hline \multicolumn{8}{|l|}{ Rf ANN-1742 } \\
\hline PI 497938 & & + & + & & & & \\
\hline PI 650362 & & & & & & & \\
\hline
\end{tabular}

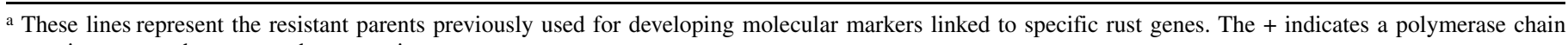
reaction pattern the same as the rust resistance parents.

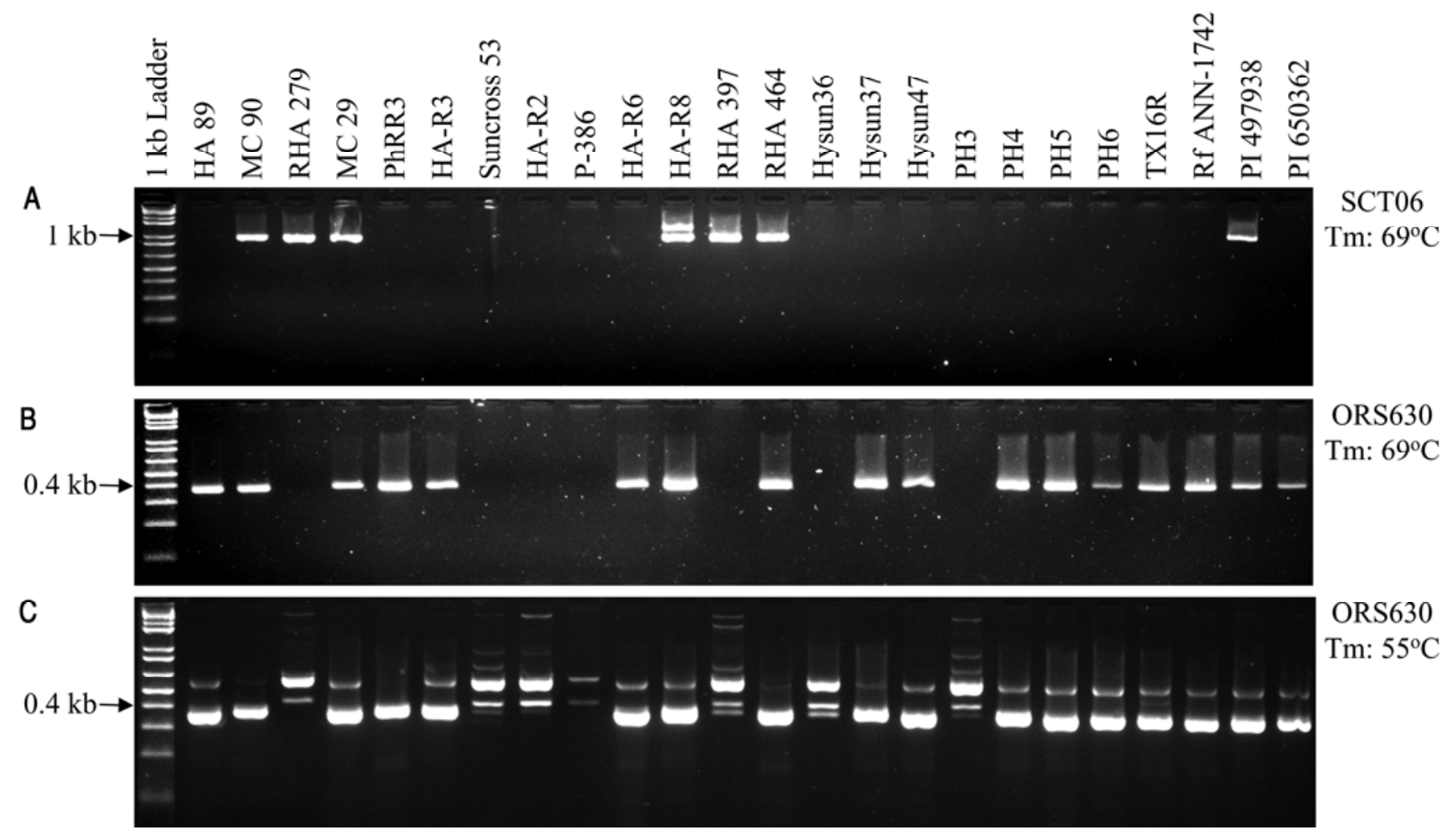

Fig. 1. Polymerase chain reaction (PCR) patterns of sequence characterized amplified region marker SCT06 and simple sequence repeat marker OSR630 in 24 selected sunflower lines. A, The SCT06-950 diagnostic fragment linked to the gene $R_{l}$ is present in two lines (MC 90 and RHA 279) harboring the gene $R_{l}$, and five other lines (MC 29, HA-R8, RHA 379, RHA 464, and PI 497938). B and C, PCR pattern comparison of the ORS630 primer at annealing temperatures of B, $69^{\circ} \mathrm{C}$ and $\mathbf{C}, 55^{\circ} \mathrm{C}$. Both gave the same results except that some minor bands were amplified at $55^{\circ} \mathrm{C}$. A 350-bp fragment linked to the gene $R_{5}$ is absent in the resistant parent HA-R2. Six other lines (RHA 279, Suncross 53, P386, RHA 397, Hysun 36, and PH3) show the same PCR pattern as HA-R2, ruling out the possibility that the missing 350-bp fragment is caused by PCR error. The molecular weight marker is a 1-kb plus DNA ladder. 
lines, RHA 279, Suncross 53, P-386, RHA 397, Hysun 36, and PH3, had the same amplification pattern for ORS630 as HA-R2, missing a 350-bp fragment (Table 4, Fig. 1B). The absence of the 350-bp diagnostic fragment due to PCR error was ruled out in these six lines. When reducing the annealing temperature from 69 to $55^{\circ} \mathrm{C}$ with the ORS630 primer, we obtained the same results except that some minor bands were amplified at $55^{\circ} \mathrm{C}$ (Fig. 1C).

\section{DISCUSSION}

Our present study revealed that most previously released rust resistant lines no longer provide effective resistance to current races such as races 336 and 777 . Among 104 entries tested, only 19 showed resistances of which 13 were resistant to both races and six were resistant only to race 336 . The existing rust resistance gene pool of sunflower has genetic diversity, which confers race-specific resistance to rust. All rust resistance genes in cultivated sunflower can be traced to wild species, mainly from wild $H$. annuus, and some from $H$. argophyllus and $H$. petiolaris $(3,18$, 19,38). Of six resistant inbred lines, HA-R2 and HA-R3 were derived from Argentina open-pollinated varieties. The rust resistance gene in HA-R2 can be traced to H. argophyllus. HA-R3 was a selection of Charata INTA, an Argentina open-pollinated variety $(3,9)$. Three wild species (H. annuus, $H$. argophyllus, and $H$. petiolaris) were involved in developing Charata INTA. The rust resistance in line HA-R6 was derived from the line PI 650362, a breeding line from France (34). PI 432512, a landrace from the Native American Havasupai tribe in Arizona, contributed its rust resistance to the line HA-R8 (Table 1) (34). The rust resistance in RHA 397 originates from germplasm obtained from South Africa and the rust resistance in RHA 464 was derived from a wild $H$. annuus accession PI 413047 collected in California (Table 1) (16,33).

The wild $H$. annuus accessions, PI 413038 (collected in South Dakota), PI 413048 (California), PI 413118 (California), PI 613748 (Oklahoma), and Texas-16 (Texas), contributed rust resistance genes to the interspecific germplasm lines PH3, PH4, PH5, Rf ANN-1742, and TX16R (Table 1) $(18,19,44)$. The rust resistance gene in the line PH6 was derived from a wild $H$. argophyllus accession PI 413171 (Table 1). Rf ANN-1742 is a new rust resistance source identified in the present study. The line MC 29 is an old Canadian line known to carry the resistance gene $R_{2}$, which was also derived from wild $H$. annuus collected in Texas (37). The information about the pedigrees of the four resistant lines introduced, Hysun 36, Hysun 37, Hysun 47, and Suncross 53, developed by two commercial seed companies in Australia, is not available, so we do not know the source of resistance gene(s) or if they are the same or different than those already identified.

The future development of sunflower inbred lines or hybrids with high levels of durable rust resistance will depend on the ability to select genotypes that have combinations of effective resistance genes. Knowledge of virulence evolution of the pathogen population and available DNA markers closely linked to host $R$-genes are a prerequisite for successful gene pyramids. The selection of the genotypes with gene combinations is often not possible using resistance tests. We have evaluated the molecular markers which were previously reported to be linked to the different rust resistance genes in 24 selected lines. Two codominant SSR markers, ORS45 and ORS799 linked to the $R_{4 u}$ gene, gave a unique pattern in the parental line Suncross 53, except the line Hysun 47 shared the same pattern as Suncross 53. We do not know if the two lines had the same gene due to lack of the pedigree information. However, three dominant PCR markers that were previously reported to cosegregate with $R$-genes of $R_{l}$, $R_{2}$, and $R_{5}$, respectively, showed cross-amplification among the different lines known to harbor different $R$-genes.
SCT06 primers amplified a 950-bp fragment associated with the $R_{l}$ gene in the lines MC 90 and RHA 279 which harbor the $R_{l}$ gene. This fragment was also present in five other lines, MC 29, HA-R8, RHA 397, RHA 464, and PI 497938. MC 90 and MC 29 have similar origins, whose resistances were derived from the outcross of the wild $H$. annuus grown in Renner, Texas, but differ in their reaction to rust (37). The rust resistance gene $R_{2}$ in MC 29 was known to be inherited independently from the gene $R_{l}$ in MC $90(27,37)$. The presence of the SCT06-950 fragment in MC 29 was previously reported and was explained by recombination between the genomic region amplified as SCT06 950 and the $R_{l}$ gene during creation of the MC 29 line (23). PI 497938 is a cultivar developed in Russia. Putt and Sackston (37) mentioned that resistance to sunflower rust in Russia had been obtained from Texas wild $H$. annuus. Our present study supports this hypothesis. PI 497938 produced the SCT06-950 fragment known to be derived from Texas wild $H$. annuus. In addition, PI 497938 showed the same PCR pattern as both MC 29 and MC 90 with the SSR marker ORS333 linked to the $R_{2}$ gene in MC 29. Both MC 29 and PI 497938 were resistant only to race 336 . It may be assumed that resistance to rust in PI 497938 and MC 29 could have been derived from the same wild sunflower source in Texas.

The $R_{l}$ gene in RHA 279 was also derived from a wild $H$. annuus from Texas, T66002-2. Both inbred lines RHA 397 and RHA 464 have SCT06-950 fragments present that could be traced to T66002-2 in their pedigree and the line HA-R8 had T66008-2, a sister line of T66002 in its pedigree (21; http://www.ag.ndsu.nodak.edu/aginfo/seedstock/varieties/VH-SUNF.htm). Similar to MC 29, these three lines have new rust genes different from the $R_{l}$ gene from the other sources. However, we do not know if the $R_{l}$ gene is also present in these lines because virulence studies can not distinguish the $R_{l}$ gene from others in these lines. The DNA fragment related to the SCT06 marker from the wild sunflower when transferred to cultivated sunflower by means of recombination seems to be preferentially transmitted in the progeny. False positives caused by similar genetic backgrounds may complicate identification of the $R_{1}$ gene when using the SCT06 marker.

SSR marker ORS333 is a dominant-repulsion marker associated with the $R_{2}$ gene in MC 29, and the absence of a 150-bp fragment is diagnostic for the $R_{2}$ gene in line MC29 (W. R. Lawson, personal communication). However, three lines, MC 90, PhRR3, and PI 497938, were found to have a similar PCR pattern to that of MC 29 with a missing 150-bp fragment. It further confirmed that three lines, MC 29, MC 90, and PI 497938, have similar genetic backgrounds originating from the wild $H$. annuus as discussed above. The line PhRR3 carrying the $R_{3}$ gene was derived from a backcross between susceptible S37-388 with resistant hybrid Hysun 33. The rust resistance in this hybrid can be traced to the male parent that was developed from an Argentina open-pollinated cultivar Peheun INTA $(8,22)$. A Canadian line 953-102-1-1-22-4 was used in the pedigree of Peheun INTA. This Canadian line is a sister line of 953-102-1-1-22 that was the resistance donor parent of MC $29(3,22,37)$. This would explain why PhRR3 had a similar PCR pattern of ORS333 to MC 29.

Sendall et al. (45) reported that SSR marker ORS630 cosegregated with the $R_{5}$ gene in line HA-R2. However, this report provided little detail on the mapping of this gene. Out of the six lines sharing the same PCR patterns as HA-R2, three, P-386, Suncross 53, and PH3, were known to carry different alleles at the R4 locus, whereas HA-R2 carries the $R_{5}$ gene $(34,45)$. Three other lines, RHA 279, RHA 397, and Hysun 36, have diverse genetic backgrounds with different reaction to rust. The apparent absence of the particular 350-bp fragment of ORS630 in these six lines may not relate to the $R_{5}$ gene. One possibility could be diverse DNA sequences in the ORS630 primer binding sites in these lines, resulting in no amplification. A combination of ORS630 with other markers flanking the gene $R_{5}$ must be used for effective identification of the gene $R_{5}$ in genotypes for backcross-assisted 
selection or for pyramiding this gene with different sources of resistance.

The present study revealed that pedigree relationships influence the association of a PCR fragment with a particular resistance gene in different sunflower lines which harbor different $R$-genes, but share the similar PCR pattern of a given marker. It complicates the use of these markers in breeding programs by means of marker-assisted selection (MAS). To improve the efficiency of MAS, it is important that the recombination frequency between the target gene and the marker be as low as possible. Developing a molecular marker which is located within the rust resistance gene (gene-specific marker) will eventually solve this problem; however, these kinds of markers are the most difficult to find. Using a combination of the markers flanking a resistance gene is a choice to effectively identify a target gene in breeding programs.

\section{ACKNOWLEDGMENTS}

We thank X. Cai and S. S. Xu for critical review of the manuscript and A. Hogness and M. Ramsett for excellent technical assistance. This project was supported by the USDA-ARS CRIS Project No. 5442-21000034-00D. Mention of trade names or commercial products in this article is solely for the purpose of providing specific information and does not imply recommendation or endorsement by the U.S. Department of Agriculture.

\section{LITERATURE CITED}

1. Berglund, D. R. 2008. 2007 National Sunflower Association Survey: Yield, cultural practices and yield limiting factors. In: Proc. 30th Sunflower Research Workshop. National Sunflower Association. Available at http://www.sunflowernsa.com/research/research-workshop/documents/Berglund_2007_NSA_Survey_08.pdf.

2. Burke, J. M., Tang, S., Knapp, S. J., and Rieseberg, L. H. 2002. Genetic analysis of sunflower domestication. Genetics 161:1257-1267.

3. de Romano, A. B., and Vázquez, A. N. 2003. Origin of the Argentine sunflower varieties. Helia 26:127-136.

4. Fick, G. N., Kinman, M. L., and Zimmer, D. E. 1975. Registration of 'RHA 273' and 'RHA 274' parental lines. Crop Sci. 15:106.

5. Fick, G. N., Kinman, M. L., and Zimmer, D. E. 1979. Registration of HA 290 sunflower parental lines. Crop Sci. 19:422.

6. Fick, G. N., Zimmer, D. E., and Kinman, M. L. 1974. Registration of six sunflower parental lines. Crop Sci. 14:912.

7. Fick, G. N., Zimmer, D. E., and Zimmerman, D. C. 1979. Registration of six nonoilseed sunflower parental lines. Crop Sci. 19:422.

8. Goulter, K. C. 1990. Breeding of a rust differential sunflower line. Pages 120-124 in: Proc. 8th Australian Sunflower Association Workshop. J. K. Kochman, ed. Australian Sunflower Association, Toowoomba, Australia.

9. Gulya, T. J. 1985. Registration of five disease-resistant sunflower germplasms. Crop Sci. 25:719-720.

10. Gulya, T. J. 2006. The sunflower rust situation: Current races in the northern and central Great Plains, and resistance in oilseed and confection hybrids. In: Proc. 28th Sunflower Research Workshop. National Sunflower Association, Bismarck, ND. Available at http://www.sunflowernsa.com/research/research-workshop/documents/Gulya_Rust_06.pdf.

11. Gulya, T. J., Kong, G., and Brothers, M. 2000. Rust resistance in wild Helianthus annuus and variation by geographic origin. Pages 138-142 in: Proc. 15th Intl. Sunflower Conf., Toulouse, France.

12. Gulya, T. J., and Markell, S. 2009. Sunflower rust status-2008 race frequency across the Midwest and resistance among commercial hybrids. National Sunflower Association. Available at http://www.sunflowernsa.com/uploads/Gulya_RustStatus_09.pdf.

13. Gulya, T. J., and Masirevic, S. 1988. International standardization of techniques and nomenclature for sunflower rust. Page 10 in: Proc. 10th Sunflower Research Workshop. National Sunflower Association, Bismarck, ND.

14. Gulya, T. J., and Masirevic, S. 1996. Inoculation and evaluation methods for sunflower rust. Pages 31-38 in: Proc. 18th Sunflower Research Workshop. National Sunflower Association, Bismarck, ND.

15. Gulya, T. J., Venette, R., Venette, J. R., and Lamey, H. A. 1990. Sunflower rust. NDSU Ext. Ser. Bull. p. 4, Fargo, ND.

16. Hulke, B. S., Miller, J. F., and Gulya, T. J. 2010. Registration of the restorer oilseed sunflower germplasm RHA 464 processing genes for resistance to downy mildew and sunflower rust. J. Plant Registration 4:249-254.
17. Hulke, B. S., Miller, J. F., Gulya, T. J., and Vick, B. A. 2010. Registration of the oilseed sunflower genetic stocks HA 458, HA 459, and HA 460 possessing genes for resistance to downy mildew. J. Plant Registration 4:93-97.

18. Jan, C. C., and Gulya, T. J. 2006. Registration of a sunflower germplasm resistant to rust, downy mildew and virus. Crop Sci. 46:1829.

19. Jan, C. C., Quresh, Z., and Gulya, T. J. 2004. Registration of seven rust resistance sunflower germplasms. Crop Sci. 44:1887-1888.

20. Kong, G. A., Goulter, K. C., Kochman, J. K., and Thompson, S. M. 1999. Evolution of Puccinia helianthi pathotypes in Australia. Austral. Plant Pathol. 28:320-332.

21. Korell, M., Moseges, G., and Friedt, W. 1992. Construction of a sunflower pedigree map. Helia 15:7-16.

22. Lambrides, C. J. 1992 Inheritance of rust resistance in sunflower, Helianthus annuus. M.Sc. Thesis, Department of Crop and Weed Sciences, North Dakota State University, Fargo, ND.

23. Lawson W. R., Goulter, K. C., Henry, R. J., Kong, G. A., and Kochman, J. K. 1998. Marker assisted selection for two rust resistance genes in sunflower. Mol. Breed. 4:227-234

24. Lilliboe, D. 2008. Reining in rust. The Sunflower. Dec. 34(6):12-15. National Sunflower Association. Available at https://www.sunflowernsa.com/magazine/details.asp?ID=558.

25. Limpert, E., Clifeord, B., Dreiseitl, A., Johnson, R., Müller, K., Roelfs, A., and Wellings, C. 1994. Systems of designation of pathotypes of plant pathogens. J. Phytopathol. 140:359-362.

26. Markell, S. 2008. Rust damage and control: Early appearance of sunflower rust is a cause for concern in North Dakota. Folicur is now available along with Headline and Quadris. National Sunflower Association. Available at http://www.sunflowernsa.com/growers/default.asp?contentID $=367$.

27. Miah, M. A. J., and Sackston, W. E. 1970. Genetics of rust resistance in sunflowers. Phytoprotection 51:1-16.

28. Miller, J. F. 1986. Registration of three nonoilseed sunflower midge tolerant bulk populations and three midge tolerant germplasm lines. Crop Sci. 26:1091-1092.

29. Miller, J. F. 1986. Registration of five nonoilseed sunflower female germplasm lines. Crop Sci. 26:1264-1265.

30. Miller, J. F., Fick, G. N., Zimmer, D. E., and Roath, W. W. 1981. Registration of three nonoilseed sunflower parental lines. Crop Sci. 21:638.

31. Miller, J. F., and Gulya, T. J. 1985. Registration of four Verticillium wilt resistant sunflower germplasm lines. Crop Sci. 25:718.

32. Miller, J. F., and Gulya, T. J. 1988. Registration of six downy mildew resistant sunflower germplasm lines. Crop Sci. 28:1040-1041.

33. Miller, J. F., and Gulya, T. J. 1997. Registration of eight maintainer (HA 393, HA 394 and HA 402 to HA 407) and seven restorer (RHA 395 to RHA 401) sunflower germplasm lines. Crop Sci. 37:1988-1989.

34. Miller, J. F., and Gulya, T. J. 2001. Registration of three rust resistant sunflower germplasm populations. Crop Sci. 41:601.

35. Miller, J. F., Rodriguez, R. H., and Gulya, T. J. 1988. Evaluation of genetic materials for inheritance of resistance to Race 4 rust in sunflower. Pages 361-365 in: Proc. 12th Intl. Sunflower Conf., Intl. Sunflower Assoc., Paris, France.

36. Miller, J. F., Zimmerman, D. C., Vick, B. A., and Roath, W. W. 1987. Registration of sixteen high oleic sunflower germplasm lines and bulk population. Crop Sci. 27:1323.

37. Putt, E. D., and Sackston, W. E. 1963. Studies on sunflower rust. IV. Two genes, $R_{l}$ and $R_{2}$ for resistance in the host. Can. J. Plant Sci. 43:490-496.

38. Quresh, Z., Jan, C. C., and Gulya, T. J. 1993. Resistance to sunflower rust and its inheritance in wild sunflower species. Plant Breed. 110:297-306.

39. Rashid, K. Y. 2004. Local epidemics of sunflower rust in Manitoba in 2003-New races or favorable environmental conditions? In: Proc. 26th Sunflower Research Workshop. National Sunflower Association, Bismarck, ND. Available at http://www.sunflowernsa.com/research/ research-workshop/documents/140.PDF.

40. Rashid, K. Y. 2006. Sunflower rust races in Manitoba. Agriculture and Agri-Food Canada. Available at http://www.umanitoba.ca/afs/agronomists_conf/proceedings/2006/Rashid_sunflower_rust_races.pdf.

41. Roath, W. W., Miller, J. F., and Gulya, T. J. 1981. Registration of RHA 801 sunflower germplasm. Crop Sci. 21:479.

42. Roath, W. W., Miller, J. F., and Gulya, T. J. 1987. Registration of six oilseed sunflower parental lines. Crop Sci. 27:825-826.

43. Sackston, W. E. 1962. Studies on sunflower rust. III. Occurrence, distribution, and significance of race Puccinia helianthi Schw. Can. J. Bot. 40:1449-1458.

44. Seiler, G. J., and Jan, C. C. 1997. Registration of 10 interspecific germplasm fertility restoration populations for sunflower PET1 malesterile cytoplasm. Crop Sci. 37:1989-1991.

45. Sendall, B. C., Kong, G. A., Goulter, K. C., Aitken, E. A. B., Thompson, S. M., Mitchell, J. H. M., Kochman, J. K., Lawson, W., Shatte, T., and 
Gulya, T. J. 2006. Diversity in the sunflower: Puccinia helianthi pathosystem in Australia. Australas. Plant Pathol. 35:657-670.

46. Tang, S., Kishore, V. K., and Knapp, S. J. 2003. PCR-multiplexes for a genome-wide framework of simple sequence repeat marker loci in cultivated sunflower. Theor. Appl. Genet. 107:6-19.

47. Tang, S., Yu, J. K., Slabaugh, M. B., Shintani, D. K., and Knapp, S. J. 2002. Simple sequence repeat map of the sunflower genome. Theor. Appl. Genet. 105:1124-1136.

48. Trevet, I. W., Rawson, A. J., Cherry, E., and Saxon, R. B. 1951. A method for the collection of microscopic particles. Phytopathology 41:282-285.

49. Yang, S. M., Antonelli, E. F., Luciano, A., and Luciani, N. D. 1986.
Reactions of Argentine and Australian sunflower rust differentials to four North American cultures of Puccinia helianthi from North Dakota. Plant Dis. 70:883-886.

50. Yang, S. M., Dowler, W. M., and Luciano, A. 1989. Gene $P u_{6}$ : A new gene in sunflower for resistance to Puccinia helianthi. Phytopathology 79:474-477.

51. Yu, J. K., Tang, S., Slabaugh, M. B., Heesacker, A., Cole, G., Herring, M., Soper, J., Han, F., Chu, W. C., Webb, D. M., Thompson, L., Edwards, K. J., Berry, S., Leon, A. J., Grondona, M., Olungu, C., Maes, N., and Knapp, S. J. 2003. Towards a saturated molecular genetic linkage map for cultivated sunflower. Crop Sci. 43:367-387. 